\title{
Observations on Some of the Principal Portraits of Devonshire Worthies
}

\section{George Scharf F.S.A.}

To cite this article: George Scharf F.S.A. (1874) Observations on Some of the Principal Portraits of Devonshire Worthies, Archaeological Journal, 31:1, 3-28, DOI: 10.1080/00665983.1874.10851629

To link to this article: http://dx.doi.org/10.1080/00665983.1874.10851629

$$
\text { 册Published online: } 14 \text { Jul } 2014 .
$$

Submit your article to this journal $\lceil\pi$

Q View related articles $₫$ 


\section{OBSERVATIONS ON SOME OF THE PRINCIPAL PORTRAITS OF DEVONSHIRE WORTHIES.}

(Including some from Cornwall, exhibited during the Archæological Institute Congress at Exeter, 1873.)

By GEORGE SCHARF, F.S.A., Kecper and Secretary of the National Portrait Gallery.

THose who had the good fortune to visit the collection of portraits of Devonshire worthies, formed last autumn in the Albert Museum at Exeter, could hardly fail to be impressed with the number, variety, and high order, both of the subjects represented, and of the manner in which they were depicted. On the latter ground, there is indeed no reason for surprise, when we remember how very large a proportion of our most eminent painters sprang from the south-western counties.

In submitting the following observations upon the collection, it is not my intention to dwell minutely upon every name of distinction, or to discuss even the claims and pretensions of many of the portraits entered in the catalogue, as issued at the time of the exhibition. I shall simply invite attention to those portraits which best represent the characters of highest eminence in connection with the counties of Devonshire and Cornwall, and dwell upon those pictures which are also deserving of notice for artistic merit, being the production of artists belonging to those counties.

I propose to treat my subjects in groups according to their rank, professions, or particular circumstances in life, and to divide these again according to the centuries to which they belonged. I shall in each case quote the number of the painting from the second edition of the catalogue, which has been prepared with great care and with the advantage of an excellent index, and sold at the Gazette Office, High Street, Exeter.

As generally happens in exhibitions formed by contributions on loan, each portrait was explicitly described in the 
catalogue by the sender, and consequently, in very many instances, according to the information, prejudice, or ignorance of the owner. Hence some pictures included in the catalogue, have by such entirely groundless pretensions, been debarred from notice altogether. Others, owing to misapprehension of the owners, although not what they are described to be, are perfectly genuine pictures, and in some instances even of merit and interest beyond what had been claimed for them. I should not do justice to my own feelings were $I$ at the outset to neglect an opportunity of expressing my admiration at the expeditious and effective manner in which the portraits collected at Exeter, were arranged on the spacious walls of the apartments destined to receive them. The untiring zeal and energy of the Rev. F. T. Colby, B.D., and of Mr. Bartholomew Gidley, M.A., deserve the fullest acknowledgment.

The earliest portrait to which I will invite attention is that of Sir John Fortescue (No. 66), appointed by King Henry 6 th Chief Justice of the King's Bench, 1442, and ranked by Lord Campbell among the Lord Chancellors of England (vol. i. p. 375). He was author of the famous work, "De Laudibus Legum Angliae," and died in 1485.

The picture is not contemporary, but of a remote period, belonging to the school of Mabuse (1499-1562). It appears to have formed part of the wings of an altar-piece, and represents the "Donatore." His wife probably occupied the companion panel. The figure is half-length, turned towards the right, with hands joined in prayer, wearing a pale scarlet gown faced with black, and a brown fur trimming to the wrists and under garment. The face is close shaven and the hair cut square. He wears a plain black cap, and the background is a tranquil blue sky, becoming paler as it descends. The neck is bare and does not exhibit any badge of judicial authority. The countenance, moreover, is that of a very young man, and Fortescue, who was born 1395 and died at the age of ninety, would at that age have worn a very different costume. His recumbent effigy in judicial robes still remains in Ebrington Church, Gloucestershire, but possibly executed at a later period. Even in those times, during the wars of the Roses, judges wore an official robe with a large tippet or cape and a hood. Sir William Gascoyne's effigy in close-fitting hood, still exists in 
Harward Church, Yorkshire (see Planche, "Dramatic Costume," London, 8vo, 1824. Henry 4th, p. 25 ; Fairholt's "Costume in England," p. 170), and affords a good example of the fashion prevailing. A curious representation of the Court of King's Bench, with five presiding judges, of the time of Henry VI., has been published in colours, from a highly finished illumination, in the Archaeologia, vol. xxxix. p. 359. The robed figure of a judge from a MS. of the date 1503 , is engraved in Strutt's Regal Antiquities, plate 50.

Faithorne and Vandergucht made engravings of a similar figure of Fortescue to this. (See the frontispiece to the folio edition, "de Laudibus," 1741, with Mr. Selden's preface and notes.) A descendant of this eminent judge held a high position in the time of Elizabeth. He also was Sir John Fortescue, and tutor to the Queen when Princess (or overseer, as Fuller calls it, vol. i. p. 282, of her liberal studies). She made him Chancellor of the Exchequer and Duchy of Lancaster, and one of her Privy Council. Selden says that he was a great master of the Greek and Latin tongues. ${ }^{1} \mathrm{He}$ was buried near Newport in Buckinghamshire, July 4, 1608.

I am not aware of any other representation of Sir John Fortescue. This picture was contributed by Earl Fortescue to the Portrait Exhibition at South Kensington in 1866, and is No. 21 of the catalogue. The execution is tender and delicate, with deep red-brown shadows on the face. The hair and eyes are dark brown. It is in good condition.

Richard Fox, Bishop of Exeter (1466-1528); a curious panel picture (No.49), contributed by Mr. Kerslake, is a mere wreck, but at the same time thoroughly genuine, so far as remains of it. It may be compared with the well-known picture belonging to Corpus Christi College, which formerly bore upon the original frame, the name of the painter, Johannes Corvus. See a note upon this painter in the Archaeologia, vol. xxxix. p. 47.

The head is here represented between two similar shields of arms, denoting Exeter and Winchester, that only on the right is encircled by the garter. He rests both hands on a staff.

Hugh Oldham, Bishop of Exeter (Bp. 1504, died 1519). A three-quarter standing figure (No. 38) holding a stick and resting his left hand on a book laid on a cushion, contributed

1 See Selden's Preface to De Laudibus, p. 52. 
by Corpus Christi College, Oxford. The glass which now protects it has been placed there too late. The picture is seriously destroyed by repainting in the coarsest and clumsiest manner. To judge by the attitude and accessories, the picture must have originally been painted from the life, although always in a hard, Chinese kind of manner, and not improbably by Johannes Corvus, who also painted the Oxford portrait of Fox. This picture was likewise at the Kensington Exhibition, No. 40 of the catalogue.

Of royal personages during the sixteenth century, we do not meet with any examples, but a group of distinguished noblemen of the Courtenay and Harington families claims particular attention.

Henry Courtenay, second Earl of Devon and first Marquis of Exeter (No. 68), (created 1525), famous for his chivalry at tournaments, and an ephemeral favourite of King Henry 8th, is seen in black armour, resting his right hand on a helmet, with a shield of arms and three crests above it in the upper left hand corner. The picture certainly belongs to his latest time, if not actually subsequent to his career. The small ruff and style of armour would seem rather to belong to the period of Queen Mary. The motto below the shield is "Lapsus ubi quid fecit, 1539." His countenance bears close resemblance to that of his son, Edward Courtenay, Earl of Devonshire, so deeply interested in the fortunes of the Princess Elizabeth, under the persecution of her sister, Queen Mary. His portrait, in the possession of the Duke of Bedford, has been many times engraved. A very faithful copy in oil, the same size as the original, was contributed to this exhibition by the Earl of Devonshire (No. 25). The circular round castle in the background was probably Plympton, which belonged to the family. ${ }^{2}$

The Marquis, his father, was the tenth Earl of Devonshire, and son of the Princess Katherine Plantagenet, daughter of King Edward IV. In 1536 he sat in judgment upon Anne Boleyn, and was soon after accused of high treason in having corresponded with his banished kinsman, ${ }^{3}$ Reginald Pole, Dean of Exeter and afterwards Cardinal and Archbishop of Canterbury, convicted without proof and beheaded.

2 Collins's Peerage, ed. 1779, vol. vi. $\quad$ * Lodge, vol. ii. pl. 29. p. 249. 
Cardinal Pole was Dean of Exeter from 1527 to $1537 .^{4}$ Of him various portraits are in existence. None, however, were to be seen in this collection.

Of Hilliard-or to adopt his own spelling, HILLYARD,although born at Exeter, and the first native portrait painter of special distinction in England, we have no representation. Queen Elizabeth sat to him frequently, and he painted many of the most distinguished persons of her court. He was born in 1547, and died January 7, 1619 . He was buried in St. Martin's-in-the-Fields, London.

His own portrait when a boy, and that of his father, Richard Hilliard, High Sheriff of the City of Exeter and County of Devonshire in 1560, is in the collection of Lord De Lisle; and another of himself at a later period belongs to the Duke of Buccleuch. Another, formerly the Earl of Oxford's, is now in the collection of the Duke of Portland at Welbeck. An exquisite miniature of Queen Elizabeth by Hilliard was purchased by Mr. C. S. Bale from Stowe, and is in perfect condition. Equally interesting, and belonging to an earlier period, is one painted on the back of a playing-card (the Queen of Hearts), now in the National Portrait Gallery. An extremely fine circular medallion portrait of his wife, Alice Brandon, daughter of the Chamberlain of London, was purchased a few years since by the Duke of Buccleuch. Hilliard does not appear to have left any personal recollections of himself in his native county. Another early miniature painter, John Shute, whose works are no longer distinguishable, was even a precursor of Hilliard, and born at Collumpton, in Devonshire. He is praised in Heydock's translation of "Lomazzo on Painting," 1598.

Another Devonshire artist, Nicholas Stone, a sculptor of considerable renown, although belonging to the succeeding century, may best be named in this place. His works are to be met with in all parts of the country, and associated with the greatest names of the day, inasmuch as he executed the monumental effigies of eminent persons; and his pocketbooks, preserved in the pages of Walpole's "Anecdotes" (D. and W., p. 239), afford a copious list and a curious illustration of the condition of monumental art in those days. He died in 1647, and was buried in St. Martin's-in-

4 Le Neve's Fasti. 
the-Fields, London. He was also a copyist in oil colours. Some of his works are still preserved at Hampton Court Palace.

We may now advantageously take into consideration an interesting group of portraits contributed by the Rev. Edward Charles Harington, Chancellor to the Cathedral of Exeter, and principally relating to the Harington family. With the exception of the first lord, I am not, however, aware that they have any immediate connection with the County of Deronshire.

The first is a curious picture, No. 124, of Sir John and Lady Harington, two half-length figures standing side by side, looking at the spectator, each wearing a large round radiating ruff, and attired in richly-embroidered Court dresses. Sir John, Queen Elizabeth's "saucy godson," is the well-known translator of Ariosto, and son of that John Harington who was imprisoned in the Tower by Queen Mary for holding correspondence with the Princess Elizabeth. Sir John was knighted in Ireland by the Earl of Essex, and enjoyed, with occasional interruptions, the favour of his Sovereign. His poem "To the Queen's Majesty" is signed "From your Highnesse Saucy Godson." 5 Some of his private letters afford curious insight into the bodily condition of Elizabeth in her declining life. The lady here represented is repeatedly mentioned in the "Nugae" as "My Mall," but I do not find any particulars as to her family. The Queen appears (page 223) to have held her in friendly intercourse. Fuller, in his "Worthies," (vol. ii. p. 287), speaks highly of his literary attainments. He here appears as a very dark man with a long thin face and pointed black beard. The face accords with the well-known engraving, the frontispiece to his translation of "Orlando Furioso," with a watch on a table before him, dated 1591, aged 30 . There is no inscription on this picture. Harington was born at Kelston, near Bath, in 1561, and died in $1612 .^{6}$

A very interesting picture, No. 130, represents Sir John Harington, who succeeded his father in the knighthood, 1592, which is the date upon this picture. He afterwards was raised to the peerage by James I. in July, 1603. He had been tutor to the Princess Elizabeth, and died at Worms,

5 Nugae, ed. 1779, vol. ii. p. 217, ${ }^{6}$ Richardson, pl. 117 ; Bromley, p. 57. and pp. $65,78,209,223$. 
when attending her at Heidelberg, on the occasion of her marriage to Frederick, Elector Palatine, 1613.7 She was afterwards Queen of Bohemia. The bust of Lord Harington appears in this picture life-size, wearing a large radiating ruff, by the side of a large shield of arms, to the spectator's left. The first half of the shield contains eighteen quarterings. The first quarter of the second half is that of his wife, Anne Kelloway, daughter of Robert Kelloway, Surveyor of the Court of Wards and Liveries. ${ }^{8}$ She survived her husband. Her mother was daughter of Sir - Boulsted. Sir John's face is ruddy, with brown curly hair and grey eyes. Only the shoulders are seen, and the dark dress is not easily to be distinguished from the deep brown background. The nose appears less aquiline than in the engraving by Pass in the "Herwologia," but the latter was done after" some interval of time, having been published in the year 1620.

The portrait No. 129, erroneously called the "Protector Seymour." Somerset never wore such a costume, and was a very different looking personage. This is in reality the second Lord Harington, son to the preceding, who was born at Combe Abbey, the property of his mother, the heiress of Kelloway. ${ }^{9}$ He only held the title one year, and died at the early age of 22. He was remarkable for his piety, and was a liberal benefactor to Sidney College, Cambridge. $\mathrm{He}$ died at Kew. Thane ${ }^{1}$ says of him: "The pious and amiable Lord Harington, who had been occasionally the companion of Henry Prince of Wales" (his father was tutor to the Prince's sister), "died at the age of 22 ; his learning and experience was far beyond his years." This picture corresponds exactly with the engraving by Pass in the "Herwologia," p. 134. It is painted on canvas, in a greyish tone, with much care, and is probably the work of Kay, one of the leading foreign artists of this period. Harington appears with Prince Henry in the well-known hunting group (killing a stag) at Wroxton Abbey. As Harington died unmarried, his property passed to his two sisters, Lucy and Frances.

Lucy Harington, who became wife of Edward, third Earl of Bedford, and was remarkable for her display and extra-

7 Fuller's Worthies, vol. ii. p. 243.

8 College of Arms, Vincent, 10.

9 Fuller, vol. ii. p. 419.

1 British Gallery of Historical Por. VOL. XXXI. traits, vol. i. p. 33 . London. 4 vols. 8 vo. 
vagance, is here easily recognised in a picture No. 125, although it bears a different name in the catalogue, and has moreover a doubtful inscription on its surface. The picture in question is a half-length on panel, wearing a large round ruff, deep full embroidered sleeves, and a large rope of many gold chains. It is called the "Princess Elizabeth," and the inscriptions on the panel are " ETATIS SV A 20 ," on one side of the head, and "Ano Dn, 1533," on the other. It is stated to have been given by her to John Harington, father of the poet (ante, No. 124). But Elizabeth, when only 20 years of age, never wore such a ruff. These large circular radiating ruffs did not come into fashion till the close of the sixteenth century.

A small oval plate inserted in the 1769 edition of Harington's "Nugae" displays a similar inconsistency. It is described on the title-page, "with the original plate of the Princess Elizabeth, engraved 1554," and at page 90 of the text it is said that the Princess gave the plate to Isabella Markham, mother of Sir John Harington, and one of her ladies about that date. The head is turned the same way, and has a similarly large round ruff. It may possibly represent the Queen of Bohemia, who, when Princess Elizabeth, was under Harington's tuition. ${ }^{2}$

It would not be unnatural to look in this group for a portrait of Prince Henry, the friend of young Lord Harington (for the two appear together in the well-known huntingpiece at Wroxton, by Van Somer), but no head there accords with the well-known type of that promising heir to the throne. ${ }^{3}$ A picture, No. 123, described in the catalogue as "a very curious portrait," and called "Prince Henry," is certainly a very different person. It represents a lady in a hat and long feather, square-cut collar, and low dress with full sleeves and lace cuffs, holding a small shell-shaped jewel at the end of a gold chain. Her white dress is embroidered with silver. Green curtains fall on each side behind. The hair is pale yellow, and the complexion fair. The features are sufficiently long to warrant the suggestion that the portrait might have been intended for Queen Anne of Dnm rk.

Two other portraits of ladies, Nos. 121 and 122, of this period appeared to be genuine and well painted : but from

2 Granger, vol. i. p. 189.

3 Observations on Ruffs. 
their position I could not sufficiently examine them. No. 121 is evidently a fine specimen of Marc Gheeradts.

A male portrait, No. 128, of an old man in black cap and curled moustaches, called "Lord Harington," is too unlike either of the known portraits, but it might possibly be James, the father of the first lord, and husband of Lucy Sidney, of Penshurst.

An historical name, that of Thomas Howard, Earl of Suffolk, No. 174, is associated with the large panel picture contributed by the Town Council of Exeter. He was Lord High Steward of Exeter in 1621. It was principally owing to his sagacity that the Gunpowder Plot was discovered. $\mathrm{He}$ was builder of that magnificent structure in Essex, called in honour of his maternal grandfather, "Audley End," near Saffron Walden. ${ }^{4}$ The picture is dated 1618 , and his age 66 , the same year that his long tenure of office as Lord High Treasurer terminated. He belongs to a group of naval and military heroes, and was one of the principal commanders against the Spanish Armada in 1588. Afterwards, when still only Lord Thomas Howard, in 1596, he interposed in favour of Sir Walter Raleigh, to allay a quarrel with the Earl of Essex.

Of Sir Walter Raleigh, although so distinguished a native of Devonshire, and of whom genuine portraits are comparatively numerous, I regret that I cannot point to a single example.

Of Sir Francis Drake, on the contrary, we have two of remarkable excellence and diversity of character. The first which I shall describe, No. 18, is from Nutwell Court, contributed by Sir Francis Eliot Drake, Bart., and has no date or inscription on it. It is evidently painted by Zucharo, and therefore belongs to the term of that painter's residence in England, which was limited to four years, from 1574 to 1578 . The picture is on canvas, and painted with all the largeness of style peculiar to Zucharo. It is remarkable for breadth of treatment, and the total absence of details. The oval hanging to a chain in front of his scarf is of a quite plain brown colour, and has a large pearl pendant to it. The globe also under his right hand has no marks upon it. The head forms a curious contrast with that in the painting belonging to the Corporation of Plymouth.

\footnotetext{
${ }^{4}$ Collins's Peerage, ed. 1779, vol. iii. p. 133.
} 
This picture was extremely well engraved by W. Holl, when in possession of Sir Trayton Drake, for C. Knight's Gallery of Portraits, 1835, vol. iv. page 170. Drake was about 33 when Zucharo arrived in England. The portrait of Drake engraved in the "Herwologia," page 106, is very peculiar, with a constrained turn, looking over his right shoulder. It is the oldest-looking representation that I know of him.

An intervening portrait, although on an extremely small scale, is the little miniature of Drake, dated 1581, aged 42, from the collection of the Earl of Derby, at Knowsley. It has been engraved in woodcut for Barrow's "Life of Drake."

The most important of all representations of this great hero is the panel picture, No. 5, contributed by the Corporation of Plymouth. It is painted on panel by an artist of considerable ability, and is in good preservation. I regret that both in the gallery at Exeter and in London, when it formed part of the 1866 Portrait Exhibition, No. 361 of the catalogue, the picture was hung too far from the eye for me to make such minute observations upon it as I could have wished.

Drake is represented as a half-figure, dressed entirely in black, standing behind a marble pedestal, with a panel on the front of it containing eight lines of Old English text divided into two columns. The face in all these paintings is seen in the same position. He wears a large round plain ruff, and has a cameo of the Queen, profile, to the left, set in a rich oval border, suspended by a long black ribbon round his neck. A large pearl hanging from it drops in front of the panel with lines of writing before named. $\mathrm{He}$ rests his right hand on a globe; the other is not seen. On the background, in grey letters, to the right of his hand, is inscribed, "Etatis sux 53, A n ${ }^{\circ}$ 1594." In the left upper corner is the shield of arms, with crest and mottoes, which have a peculiar interest. It has recently formed the subject of a very learned and valuable paper in the "Herald and Genealogist," part xlvi. for January, 1874, pages 307 and 309. A woodcut is there given of the arms as drawn by Vincent, and still preserved in the College of Arms.

There, as in the picture, the wyvern is introduced, but not hung up by the heels, as described by Prince, and accepted by Miss Aikin, in her "Life of Queen Eliza- 
betll," edition 1819, vol. ii. page 365 . She sets it forth as follows :- Sir Francis " had thought proper to assume, apparently without due authority, the armorial coat of Sir Bernard Drake, also a seaman and a native of Devonshire. Sir Bernard, from a false pride of family, highly resented this unwarrantable intrusion, as he regarded it ; and in a dispute on the subject gave Sir Francis a box on the ear. The Queen now deemed it necessary to interfere, and she granted to the illustrious navigator the following arms of her own device:- - Sable, a fess wavy between two pole-stars argent; and for crest a ship on a globe under ruff, with a cable held by a hand coming out of the clouds; the motto, 'Auxilio divino;' and beneath, 'Sic parvis magna' : in the rigging of the ship a wivern gules, the arms of Sir Bernard Drake, lung up by the heels."

This description is given by Prince in his account of Sir Bernard Drake, page 245. In his account of Sir Francis, the illustrious circumnavigator, a few pages earlier, page 240 , Prince snys that after his great voyage and receiving the honour of knighthood from the Queen at Deptford, 1581, "Sir Francis is said to have given for his device the globe of the world, with this motto, 'Tu primus circumdedisti me'

' Thou art the first who didst encompass me round about,' but not excluding his former motto, 'Divino Auxilio'- ' by the lielp of God.'

Another eminent navigator of this period, Sir John Hawkins (born at Plymouth about 1520, and died at sea off Dominica, 1591), so closely associated with Drake, is well represented in a panel picture (No. 1), contributed by $\mathrm{Mr}$. C. Stewart Hawkins. It exhibits a standing figure seen nearly to the knees, clad in a black suit, with short Spanish cloak, resting his right hand on the hip, and with the left, holding the hilt of his sword. His tall black hat is surrounded by a row of pearls set in silver, and a cameo medallion of the Queen with a silver spear behind it, is attached to one side next to his right ear. He wears a large and ample white ruff, and a shield of arms is in the upper left hand corner. They correspond, with the exception of the crest, a Moor with his arms corded, with the representation in the Archaeologia, vol. xxxiii. p. 206. To the right of the head is inscribed 
This, however, would alter the date of his birth to 1533 or 1534. Rose and Hole both give the approximate date of 1520. The countenance is severe and corresponds with the engraving in the "Herwologia," page 101, where he wears a similar tall hat and ruff, and grasps a baton in his right hand. The motto given below it is "Advancement by dilligence."

In the borders to the Armada series of tapestries in the old House of Lords, Hawkins was also represented. The only record of it now remaining to us is in Pine's wellknown series of engravings. There the Admirals were all represented in a somewhat uniform costume, and none of them in ruffs or with covered heads. They all wear plain square turnover collars and gorgets with breastplates. As a matter of likeness, we cannot depend implicitly upon Pine's medallions.

We look in vain in this collection for a portrait of Sir Peter Carew, of Mohun Ottery, Devon, whose life was so romantic. His portrait at Hampton Court was engraved as a frontispiece to his biography, by Sir John Maclean, and a curious MS. of his life was printed in the Archaeologia, vol. xxviii. p. 96 .

A fine head, however, of Sir Gawen Carew, Knt., who was active with Sir Peter Carew against the insurgents in Devonshire in 1549, is contributed by Mr. W. Pole Carew (No. 63). It is inscribed, "Son of Edmond, Baron of Carew ; died at Exeter, 1583." The picture has been ascribed to Hilliard, but without any proof that I am aware of.

Richard Carew, the historian and author of the Survey of Cornwall, appears in a picture painted on canvas (No. 82), the property of Mr. Tremayne. It closely resembles a panel picture contributed by Mr. W. H. Pole Carew, to the Kensington Portrait Exhibition of 1866 (No. 313 of the catalogue). Both pictures are inscribed, "1586, Aetatis Suae 32." The figure is dressed in black, holding a book, with an opaque red background. In the upper left hand corner is a quaint device of a diamond on an anvil and an arm issuing from a cloud holding a hammer over it, with the motto "Chi verace durera."

John Carew, who lost his hand at the siege of Ostend, in 1602 , and wore an iron one to supply its place,-hence his epithet, "Carew of the hand," - is represented in $\mathrm{Mr}$ 
Tremayne's picture (No. 83). He carries his arm in a sling like the Duke of Brunswick, his dress is purple and he wears a falling frill fitted close to the neck. Inscribed " Etatis suæ 39."

An excellent picture of Sir Thomas Lyttelton, M.P. for Worcestershire and High Sheriff of Staffordshire, a member of the Oxford Parliament, and afterwards confined in the Tower of London by the Parliament, was contributed by Lord Lyttelton from Hagley (No. 61). He is represented in dark armour with a rich white lace falling collar and a handsome youthful countenance. As a work of art, signed and dated, "Van Sommer, fecit 1621," it is a singularly favourable specimen of the. Flemish style of painting then so prevalent in this country, and in perfect condition.

Two portraits of a great historical character, Sir John Eliot, now claim consideration. They both come from Port Eliot, and are the property of Lord St. Germans, descendant of the patriot (Nos. 27 and 9). The first which I shall notice is very characteristic of the fanciful style in which many portraits were painted at the beginning of the seventeenth century. The figure is seen standing to the knees, wearing a straight cut dressing gown, banded with stripes of coarse geometric lace, and having a close fitting falling collar of same material, and cuffs to match. The dress is entirely white. He holds a small comb in his left hand, and the right hand is bent upon the hip. The picture is on panel and very coarsely painted, but there is a quaint and sharp look about the countenance as the eyes are fixed on the spectator. The expression is very far from solemn. The inscription on the lower part of the background, to the left,

$$
\begin{gathered}
\text { "SIR JOHN ELIOT } \\
\text { Painted a few days before } \\
\text { his Death in the Tower, } \\
\text { A.D. } 1632 \text { " }
\end{gathered}
$$

is obviously modern, and, as I take it, should have rather been applied to the picture next to be described.

The costume and style of painting certainly betoken an earlier period than 1632. The hair is strangely straight and clotted, as if he were only then about to make use of the comb. There are many portraits of ladies taken at this period, holding a comb, and when introduced, as in this pic- 
ture, can only be regarded as youthful vanity on the part of a man. It has been well engraved in stipple by F. Holl, as a frontispiece to the excellent life of Sir John Eliot, by John Forster (Second edition, 1872, vol. ii.).

The other picture, which is much better in execution (No. 9 ), is on canvas, and represents Sir John Eliot in becoming attire with his locks well arranged, a dark peaked beard and a full-plaited falling ruff fitting close to the cheek. The picture is oval within a brown spandril. The hair and beard are very dark brown. The eyes are black and the lips deep crimson. The date, 1628 , is entirely modern. In comparison with the other portrait, I consider this very superior, although in his biography of Sir John Eliot, vol. ii. p. 163, Mr. Forster speaks of this painting as "not by a master," and at page 462 , pronounces the other as "incomparably the best of the two pictures."

An interesting group of civic notabilities and local celebrities, both male and female, are next deserving of attention. It will be useless to attempt any description of them. They are all the property of the Town Council of the city of Exeter. I shall give the names and the principal dates connected with them.

Thomas White, 1566, aged 83 ; founder of St. John's College, Oxford. Granger (vol. i. p. 206) informs us that the portraits were taken from his sister, whose face closely resembled his. (No. 167.)

William Hurst, five times mayor, 1568, aged 96. (No.168.)

Joan Tuckfield, 1573, "aetatis suæ 67," is a good panel picture (No. 169), representing a venerable lady in a red gown and a black head-dress bordered with pearls. It is a very genuine picture.

Lawrence Atwill exhibits a face of great power, but unfortunately the painting has been retouched (No. 171). Coat of arms in left hand corner. He died in 1588, aged 77. By an act of Chamber, eleven years after that, 12th December, 1599, it was agreed that "Mr. Atwill's picture, which cost twenty shillings, shall be paid for." It is surely desirable to ascertain to whom the money was paid, and if possible, obtain some clue to the name of the artist.

Sir John Periam, 1616, brother to the Chief Baron of the Exchequer, was a great benefactor to Exeter Coll., Oxon., and son of the Mayor of Exeter in 1563 and 1572. He 
wears a black pointed hat, and has a round very marked face. (No. 125).

Hooker, antiquary and historian, born about 1524 (No. 172), the first Chamberlain of the city of Exeter. He was M.P. for Exeter, 1571, and assisted Holinshed in his history : he died $1601 . .^{5}$ He is represented wearing a tall hat and, large ruff, shield of arms and motto, "Post Mortem Vita," and holding a small scroll in his left hand. A square tablet to the right remains blank.

Sir Benjamin Oliver (No. 176), is a clever and well-drawn representation of an ungainly personage. He is attired in a scarlet robe and holds forth a pair of gloves in his left hand. He was Mayor of Exeter in 1670, and received the honour of knighthood on the occasion of a visit of King Charles 2nd to the city. There is no name on the picture, but from the close resemblance which it bears to the known works of Bower, who painted members of the Fairfax family, and one of Lord Keeper Finch, now at Raby Castle, I feel little or no hesitation in ascribing it to his pencil.

Elizabeth Flay. "A.D. 1673, aet. 86," is inscribed on the tablet of a frame of a pleasing and very peculiar portrait of a lady in a broad-brimmed hat, taken evidently at a much earlier period of life. Her high-crowned hat has a broad brim which tits exactly to her large and square-cut ruff, which fits close to her cheek. She is dressed in black, and holds a small prayer-book with red ribbon in her right hand. A fluted column is on the left hand side, below which is a skull, and the inscription on the pedestal, "Memento Mori." It is a very curious costume picture. She wears a large gold ring on the thumb of her right hand. Her countenance is impressive, with full indications of determination. Her eyes look steadily on the spectator. Her dress is ornamented with lace, and a black border in front of her white neckerchief is very pretty. She was a foundress of almshouses.

Leaving now this group of civic worthies, we can hardly resist pausing before the portly figure of a very important Minister of State, belonging to the reign of Charles 2nd, Sir Wm. Morice (No. 96). Having rendered the King great

5 On a portrait of Fox, Bishop of Win-
chester, in the President's Gallery at
Corpus Christi College, Oxford, is the
following inscription, in Roman capi-

roL. XXXI. tals: "HANO REPURGATAM TABELLUM RESTITUIT JOHES HOOKER GENEROSUS. Exoniensis 1579." See Archaeologia, vol. xxxix, page 48 . 
service during his exile, King Charles, in 1660, appointed him Secretary of State, an office which he retained during eight years. He wears a long wig and a handsomely embroidered under dress, with a belt, holding a silver cane or baton in his right hand. The picture was probably painted by Michael Wright, the court painter of that period. I'he upper part of the figure has been engraved by Houbraken (plate 98 of the "Illustrious Heads"), and as usual, with all transcripts till the time of Vertue, turned the reverse way. It is the property of $\mathrm{Mr}$. W. H. Pole Carew, who possesses an original letter addressed by the King, when at Brussels, to Sir William. It is dated 27th March, 1660.

There is in the Town Hall at Exeter a very striking fulllength portrait by Sir Peter Lely, of his kinsman, General Monk, in his robes as a Knight of the Garter, which is well known through the engraving of it in Lodge's portraits of Illustrious Persons. There is also in the same hall a very interesting picture of the Princess Henrietta, youngest daughter of Charles 1st, afterwards Duchess of Orleans. As she was born at Bedford House in Exeter, June 1644, this picture, painted by Lely, was presented to the Corporation by the King in 1672 . She died at Paris, 1672. She is represented in a white satin dress, standing on a carpet and holding, with one hand, the end of a gauze scarf, and with the other, slightly raising the gown. The picture is very simple, well painted, and entirely free from affectation. The background is dark and quite plain.

A contrast to this, in another royal portrait, will be found in the half-length figure of William 3rd, in armour, belonging to the corporation of the poor at Exeter (No. 158). He raises his right hand holding a truncheon, and rests the left on a block of stone with a plumed helmet on it. A fortress and besieging troops are in the distance. It is probably painted by old Wyck, but exhibits all the restlessness and affectation of pose so peculiar to the French school. It is the very reverse of what a portrait should be.

An extremely fine picture of Sir William Noy, a most learned lawyer, and an excellent specimen of the power of Cornelius Jonson van Ceulen (No. 95), was contributed by Exeter College, Oxford. He died in 1634. A similar picture was also contributed by the Hon. Mrs. Davies Gilbert (No. 80). His costume, with the falling frill or ruff, and pointed 
beard, much resembles the second portrait of Sir John Eliot, ante, p. 16.

Sir John Maynard, also the property of Exeter College, Oxford (No. 94), is an excellent picture; painter unknown. He was born at Tavistock, 1602 ; sent to the Tower in 1647 ; King's Sergeant and Knight in 1660 , a warm promoter of the Revolution. He was M.P. for Plymouth in 1690, in which year he died. $\mathrm{He}$ is represented wearing a red cape and black cap. The shadows are remarkably well massed.

John Churchill, Duke of Marlborough, K.G. (No. 117). This great general, born at Ashe in Devonshire, in 1650, was represented by one of the handsomest portraits selected from the Duke of Marlborough's collection at Blenheim Palace. ${ }^{6}$ It is a youthful portrait, a half-length in complete armour, resting a truncheon on a rock, and the helmet beside it. From the absence of the ribbon of the garter, it would appear to be one of Kneller's earliest productions, and certainly one of his most careful and refined. This picture has never been engraved, and never before been publicly exhibited.

As a contrast showing the work of the same painter, when carelessly treating an eminent character like Bishop Trelawny, and representing him in the robes of the garter, we must point to No. 37, contributed by Sir John Trelawny. The painter has produced a merely crude and harsh representation, but the picture is perfectly genuine, and only a lamentable instance of Kneller's indifference to merit and avidity for lucre. It appears to be the same portrait as that contributed by Sir John to the 1866 Portrait Exhibition at South Kensington, No. 1011 of the catalogue. When expostulated with upon his slovenliness and unworthy treatment of a subject, Kneller would reply that no one seeing the picture objected to, would suppose it to be done by the man who painted the "Converted Chinese." This celebrated picture, on which he justly prided himself, is a fulllength standing figure, painted with all the richness and power of his masters, Ferdinand Bol and Rembrandt. It is in one of the apartments at Buckingham Palace.

Sir John Rolle, K.B., a zealous supporter of the king during his exile, is a strongly pronounced specimen of the style of Sir Godfrey Kneller. It is the property of the Hon. Mark Rolle (No. 92). He wears a crimson robe and tassels,

6 Catalogue Raisonne of the pictures at Blenheim Palace, p. 193. London, 8vo, 1861. 
with a long and high-dressed wig. It is inscribed in the background over lis left hand-

Et Suæ 65

1695.

Sir William Pole, Knight, the great antiquary, appears in this collection (No. 85) under a singular aspect, being remarkably like the commonly received portraits of John Bunyan, but with the important difference that he wears a black satin dress, and that the front of his dress is fastened with jewelled studs. The picture is painted on canvas, and belongs to Sir John de la Pole, Bart.

Sir Henry Rolle, the property of the Hon. Mark Rolle (No. 86), is a very striking subject. He was M.P. for Truro in the first Parliaments of Charles 1st, and Commissioner of the Treasury in 1650. He has a long thin face, with long dark hair, black cap, and a plain square-cut collar over a black dress. The picture is painted with great power, although not at all in the style of Vandyck.

A striking picture of an amiable man, wearing peculiar robes and pointing to a coronet in a significant manner, is John Anstis, Garter King-at-arms (No. 21). It is the property of the Rev. T. Bewes. The peculiar mace of office lies on the table beside his coronet. The picture is attributed to Hudson, the master of Sir Joshua Reynolds, who also was a Devonshire man. An elaborate and very comprehensive family picture, by Hudson, may be seen at Powderham Castle. It exhibits all the characteristics of the painter, and is only equalled in regard to scale and ambition, by the great painting at Blenheim, representing the family of Charles, second Duke of Marlborough. The latter is referred to by Walpole as the painter's chef d'ceuvre. 'To return to the portrait of Anstis, although the name of Hudson seems to have been written on the back of the canvas, I am persuaded that it is really the work of Hill, a clever and very little known painter of this period. His various portraits of Wanley are capital, and that of Bishop Hooper, at Christchurch, Oxford, has been frequently attributed to Hogarth. Several of his portraits were engraved at the time. In confirmation of my views, I found subsequently in Lord Oxford's sale catalogue, the mention of a portrait of Anstis, by T. Hill, and described as an excellent half-length, in his robes. (Page 17 of catalogue, March 13th, 1742.) The style 
of workmanship of this portrait is much more nearly allied to that of Whood or Dandrige than of Hudson, who was much more solid in colour and less facile in execution. This is really a masterly performance.

A picture of a young man in an oval frame, belonging to this period, and the property of the Town Council (No.175), is called Nicholas Duck, born 1570, and died 1628. The gentleman here represented could hardly have been born earlier than 1680 . But the picture is an excellent one, possibly painted by $\mathrm{T}$. Murray, and so full of individuality, that it seems quite possible with a little perseverance that his name might, after all, be satisfactorily made out.

Peter Blundell, born at Tiverton in 1520, is said to be represented in a well-painted oval picture, contributed from Blundell's school (No. 101)。 It is painted on an oval canvas within a square frame. The face is quite young, with long flowing hair and a square laced collar with tassels. To judge from the age, costume, and style of painting, the young man represented could not have been born earlier than 1630 . A modern engraving from this picture has the name on the margin ; but that carries no conviction.

The last picture which I will venture to touch upon in the present division is a very eccentric subject, namely, Bamfylde Moore Carew, known as the king of the beggars (No. 92). It is the property of Colonel Carew. He holds a pug dog under his right arm, and looks at the spectator with a humorous expression. It is painted by an artist of whom scarcely anything is known, $\mathrm{R}$. Phelps. An effective engraving in mezzotint was executed from it by Faber. It was also engraved afterwards in a square border on 8vo size, by J. Baker, in the same way as the original.

This brings us to the threshold of what may be termed the division of modern art, beginning with Reynolds, extending to Eastlake, and including works of Northcote, Opie, and Haydon.

'I'he reputation of Gandy, of Exeter, is universally spread, and I was particularly anxious to meet with some genuine examples of his skill. James Gandy, the elder, was said to have been born at Exeter, and to have received instruction from Vandyck himself. He accompanied the Duke of Ormond to Ireland, where he died in 1689 . His best works are said to be remaining in that country. His son, William 
Gandy, settled in Exeter about 1700, and had studied under "Magdalen" Smith. He was at Plymouth in 1714, and is supposed to have ended his days at Exeter, but the period of his decease is unknown. According to a note in Walpole's Anecdotes (by Dallaway and Wornum, page 351), the younger Gandy was of great talent and eccentric genius, and died in poverty.

Mr. Samuel Redgrave, in his new and highly serviceable dictionary of English Artists, characterizes his works as occasionally "loosely finished. IIE rarely indeed finished more than the head and the hands. His best works possessed great force and power, and have been deemed like Reynolds's. He was of a proud intractable disposition, careless of his reputation; in his latter days only painting when pressed by necessity."

I did not recognize any authenticated paintings at Exeter by the earlier Gandy, James. It is just possible that two paintings in the National Portrait Gallery representing the first Duke of Ormond and his accomplished son the Earl of Ossory, both distinguished by the Order of the Garter, may have been the work of that artist. By the younger Gandy, William, two examples were prominent in the Exeter collection of Devonshire Worthies. And they certainly serve to show the talent and extreme carelessness of the painter.

John Patch, sen., Senior Surgeon of the Deron and Exeter Hospital in 1741, was an eminent professor, and is represented half-length, standing, and resting his left hand on a large open book, in front of which lies a dissected human arm. This picture (No. 151), contributed from the Hospital, is an admirable specimen of Gaudy's skill, simple and unaffected in attitude, and coloured with much richness and mellowness of tone. The arm, lying on a white cloth, is admirably painted.

The other picture is a pretentious full-length, a standing figure in a scarlet robe and long wig, holding forth a paper in his left hand. A helmet is behind him. This represents Sir Edward Seaward, Kt., Mayor of Exeter in 1691, a great promoter of the new workhouse, and benefactor to the City of Exeter. This painting (No. 158) is contributed by the corporation of the poor. On a large round-topped tablet in the lower right hand corner of the picture is inscribed in very large letters, "1702. This picture was made and given by 
Mr. Wm. Gandy." In point of artistic skill, it is totally undeserving of any particular attention.

In entering upon this portion of my account of the Devonshire Worthies, we shall find the artistic element predominating. Great and abundautly varied, and surpassing also in number as the works of Sir Joshua Reynolds were, he can hardly be said to have been adequately represented in this collection. The name of his immediate predecessor and instructor in art, Thomas Hudson, has already been mentioned, but it may be desirable to dwell a little more carefully upon his works and his sources of education.

His master, Jonathan Richardson, a good painter of a head, and author of one of the most sensible books on painting ever addressed to students, was born about 1665 , and became a pupil of the well-known Riley. The place of his birth is nowhere recorded. One of his daughters married Thomas Hudson, who was born in Devonshire in 1701, and died at Twickenham in 1779. His large family picture of the first Viscount Courtenay, in the great hall at Powderham Castle, is certainly inferior to an equally large work at Blenheim of Charles, second Duke of Marlborough, and family, described by Horace Walpole as his chef d'ceuvre. There is also at Powderham an admirable full-length of Lady Anne Courtenay, a walking figure in white satin, holding a gauze scarf, by Hudson.

His full-length picture of Lord Chancellor Camden, in the Town Hall, dated 1762, when he was Lord Chief Justice of Common Pleas, is very dignified. Also in the Town Hall is a fine stately figure of John Tuckfield, M.P. for Exeter from 1745 to 1766 . There is likewise in the Exhibition (No. 147), another portrait of him by the same artist, contributed by the Devon and Exeter Hospital.

The portraits of Handel in the National Portrait Gallery and at Oxford are perhaps the works by which Hudson is most universally known.

A contemporary painter, Francis Hayman, born also at Exeter in 1708, and who died in 1776, deserves mention. He was a clever artist in figure subjects, and yet trified his life away. He was a fast liver, somewhat learned, and made illustrations for Warburton's collective edition of Pope's works, and also for Milton's "Paradise Lost." He and his works are totally unrepresented in the present collection. 
Of Sir Joshua himself, by a singular coincidence, two pictures, the earliest and the latest which he painted, were brought together; contributed by Mr. Reynolds Gwatkin (Nos. 50 and 51).

The young picture is very interesting, as exhibiting all the freshness of youth on the features with a remarkable amount of quiet dignity and propriety about it, so different from the manner in which artists generally represent themselves. He has a plain grey drapery thrown over his shoulders. This, and the picture of him in advanced age, were exhibited at the British Institution, Pall Mall, in 1823, Nos. 42 and 43 of the catalogue.

There is in the National Portrait Gallery a well-known portrait of Reynolds by himself, when quite young, holding a palette, and shading his eyes with his hand. It belonged to his niece, Miss Palmer, afterwards Marchioness of Thomond, whose portrait, as a pretty girl caressing a dove, painted by Miss Reynolds (No. 54), was also exhibited at Exeter by the Rev. F. T. Colby. A small portrait of Sir Joshua in cap and gown (No. 52), is burnt into a piece of wood with hot irons, and commonly called a "poker painting." 7

His father, the Rev. Samuel Reynolds, son of the vicar of St. Thomas, Exeter, and Master of Plympton Grammar School (born 1680 and died 1746), was painted by Sir Joshua in profile, and plain black drapery over the shoulder. The picture belongs to the Plymouth and Cottoniau Library, and was exhibited at the Kensington Portrait Exhibition of 1867 , No. 558 of the catalogue. An idea of the general composition was afforded at Exeter, by a brilliant impression of the well-known engraving in mezzotint, by S. W. Reynolds. His uncle, Canon Reynolds, appeared in a fine picture (No. 45), contributed by the Provost of Eton College. It has not been frequently seen, but was exhibited at Manchester in 1857 , No. 54 of the catalogue. The picture was engraved effectively by $\mathrm{M}^{\mathrm{c}}$ Ardell. The hands are joined on a handkerchief in his lap.

John Dunning, Lord Ashburton, born at Ashburton, Devon, 1731, died at Exmouth 1783, is an extremely effective and solidly-painted picture, contributed by the trustees

7 This is probably the work of John Cranch, an assistant of Sir Joshua Reynolds, born at Kingsbridge, Devon, in
1751. He excelled in "Poker pictures." See Redgrave's Dictionary of Artists of the English School. London, 8vo, 1874. 
of the National Portrait Gallery (No. 67). It has this additional interest, that a written agreement was drawn up by which the painter engaged to execute the portrait in permanent colours. Even at an early period of his career, Reynolds was charged with making use of pigments which, however bright they might at first appear, were liable to fade. He not unfrequently met this by declaring that he al ways came off with fying colours.

Those who have seen Sir Joshua's larger pictures and groups arranged in the open air, can hardly fail to have observed the exquisite beauty of his landscape backgrounds. On visiting Plympton during my recent stay in Devonshire, I was particularly struck with the extreme richness of the scenery of his native place, and immediately round the castle, in the glades, and on the distant hills at once saw the component parts of his glorious creations, which he skilfully adapted to the sentiment, so as to harmonize with the attitudes of his figures. His travelling sketch-books whilst abroad contain much fewer records of natural scenery, even in Italy, than studies and notes of figures as met with in the composition of some distinguished painter.

One view, and that a bold sketch of a long shape, of Plymouth (No. 16), contributed by Earl St. Germans, is all that was shown in that department of art. It is said to have been painted before Reynolds went to Italy in 1749 .

Another Devonshire artist contemporary with Reynolds, and also a pupil of Hudson, was Richard Cosway. He was born at Tiverton in 1740 , and died at a very advanced age in 1821. He was a man of eccentric habits, master of nearly every branch of art, and excelled especially in delicately-finished miniatures. He was very uncertain, so that his productions may be said to range from very best to the very worst. By the hand of Cosway I did not observe a single specimen in the collection.

Two portraits of charming ladies merit observation at this place. Lady St. Aubyn, dated 1767, and painted by H. Schaak, is the property of the Rev. St. Aubyn Molesworth St. Aubyn (No. 55). She wears a quaintly-shaped cap, with black lace front to stomacher, a rose and jessamine at her bosom, and a blue parroquet beside her. The productions of this artist are very little known. A portrait by him of the satirist, Churchill, is in the National Portrait Gallery.

voL. XXXI. 
Lady Grenville, wife of the Chancellor of the University of Oxford, and sister of Lord Camelford, is a pleasing example of the talent of a French artist, Mlle. Vigee Le Brun, painted at Rome in 1792. The picture is the property of the Hon. G. M. Fortescue (No. 24). She is represented in the character of Hebe. The picture is mentioned by Mlle. Le Brun, in her very interesting and recently published autobiography (vol. ii. page 366). Lady Grenville died in $\mathbf{1 8 6 4 .}$.

Thomas Pitt, first Lord Camelford, father of the preceding lady, nephew of the great Lord Chatham, died in 1793 . It is painted by Romney, and contributed by the Hon. G. M. Fortescue (No. 19). He is represented seated, in scarlet suit, resting his left elbow on a table. The picture is extremely well painted, and a very favourable specimen of the skill of this celebrated rival of Sir Joshua Reynolds. Romney himself died in 1802. Lord Camelford was first cousin of William Pitt, the Prime Minister. The second Lord, his son, was killed in a duel, 1804.

The favourite pupil of Sir Joshua Reynolds, and himself a true Devonshire man, James Northcote, next claims our attention.

Northcote was the son of a watchmaker at Plymouth, and was born there October 22, 1746. He resided for a considerable time in Sir Joshua's house, and afterwards spent three years in Italy. He practised portraiture with great success, and contrived to produce many historical pictures on a large scale which in his day enjoyed a considerable amount of popularity. Many of them were engraved. His portrait of Coleridge acquired a high degree of approbation. It is, perhaps, the last representation of the poet extant. The life which he published of his friend and master, Sir Joshua, is full of interesting matter, both personal and instructive, on account of the practical knowledge which had been imparted to him during his pupilage. His "Fables" and the "Life of Titian" are also books highly esteemed for their intrinsic worth.

The results of his pencil were scantily shown in this exhibition. His own portrait, and that not a very good one, contributed by Mrs. Woolcombe (No. 56), shows him with palette and brushes in his left hand, the face in profile to the left, raising his right as if about to shade his face, with- 
out doing it, in looking at some distant object. Herein Northcote has imitated, but missed, the point of his great master's own portrait of himself, already adverted to. There the hand casts a Rembrandt-like breadth of shadow across the brows, and secures a magnificent massing of deep rich tones. In compensation was to be seen in the same room an admirable full-length, cabinet size, of the venerable artist as he sat during his latest years in his well-known studio in Argyll Street. The picture was painted by Mr. S. A. Hart, then one of his pupils, in the year 1830. It is also the property of Mrs. Woolcombe (No. 8). A portrait of Sir Joshua leans against his chair, and Northcote's grand picture of Arthur and Hubert, from Shakspeare's "King John," appears in the background.

Mr. Hart himself has since spoken to me about this picture, and related a few personal circumstances showing that it was one of his first enterprises in art.

Opie, himself a Cornish man, and the protége of another Cornish man, known to the world as "Peter Pindar," was more extensively and adequately represented at Exeter. Opie was born near Truro in 1761. An early portrait of his mother, lent by Mr. Northmore Lawrence (No. 10), is full of character. The old lady turns over the page of a very large bible before her, holding her spectacles in the right haud, and looking piercingly at the spectator. Her black cap, edged with white, is tied under her chin. A similar picture of an old woman in white cap and cloak, holding a large book, is almost Sibylline in character. This is Dolly Pentreath, one of the last persons able to converse in the Cornish language. It is contributed by Sir John St. Aubyn (No.6).

An excellent portrait of John Patch, jun., 1803, by $\mathrm{J}$. Opie, is rich and mellow in colour, full of character, and with broad mellow shadows. The cut of the wig and style of dress contradict the date attached to it. He died in 1787. A very effective engraving by Ezekiel was published from it at Exeter in 1789. The picture belongs to the Devon and Exeter Hospital (No. 152).

A late production of Opie's appears in his portrait of Davies Gilbert, P.R.S., born at St. Erth, in Cornwall, 1767. He was the early friend and patron of Sir Humphry Davy, and succeeded him as President of the Royal Society. The 
picture was contributed by the Hon. Mrs. Gilbert (No. 110). It is painted with less vigour and depth of shadow than in his previous productions. The picture is inscribed "Davies Giddy, 1805. Opie, R.A." The artist only lived two years after this date. The paternal name of Mr. Gilbert was Giddy. He assumed the former name in 1817, in consequence of marrying the daughter and heiress of Thomas Gilbert, Esq., of Eastbourne, in Sussex, where he lies buried.

A bold and picturesque character; a rugged old man, grasping a stick with both hands, and known as the "Penzance Scavenger" (No. 64), contributed by Mr. Northmore Lawrence, is an excellent example of Opie's peculiar powers.

The lineaments and the refined productions of Sir Charles Eastlake were unrepresented. The spirited Brockedon and the unfortunate martyr to his art, Haydon, and the gentle Samuel Prout, did not appear. Cosway also was an artist of such especial mark that some portrait by his hand would have been highly acceptable.

The fine countenance of Dr. Buckland, Dean of Westminster, admirably depicted by Thomas Phillips, was shown by Mr. G. C. Bompas (No. 46). That of Sir William Follett, cleverly painted by Say, is shown in No. 59. The fine head of the late Sir John Bowring, contributed by Lady Bowring (No. 119), being an enlarged photograph,. and thereby an example of the latest process by which the personal appearance of our greatest men is henceforth likely to be transmitted, falls not inappropriately to the conclusion of the series upon which I have had the honour to present these observations. 